\title{
DETERMINING THE BEST POSSIBLE SPEED OF THE SHIP IN SHALLOW WATERS ESTIMATED BASED ON THE ADOPTED MODEL FOR CALCULATION OF THE SHIP'S DOMAIN DEPTH
}

Grzegorz Rutkowski

Gdynia Maritime University, Poland

Master Mariners Association, Poland

\begin{abstract}
The purpose and scope of this article is to present the best marine practices used to determine the ship's domain depth (compared to the safety depth parameter in ECDIS) and the safest and best possible speed (also known as optimal speed) of the ship in restricted sea areas limited by the depth of navigation waters. The author also presents a method that can be used to estimate the safe speed of a ship in shallow waters and the so-called navigational risk factor (specified in the range from 0 to 1), using the safety depth parameter specified in ECDIS based on the analysis of a three-dimensional model of the ship's domain. The essence of the method proposed in this paper is a systematic approach to the operation of a seagoing ship in the aspect of assessing its navigation safety (navigational risk factor) when manoeuvring in restricted sea areas, in particular in shallow waters including navigable canals and fairways.
\end{abstract}

Keywords: safe speed, best possible speed, optimal speed, ship's domain, safety depth, under keel clearance (UKC), navigational risk factor, ship squat

\section{INTRODUCTION}

Among the most important problems arising when studying the literature on the selection of the ship's speed in restricted sea areas limited by the depth of navigation waters $[1,3,5,8,9,10,11,15,16,18,20,21,25]$, the following conclusions can be drawn:

Specific values of the speed at which the ship should operate in restricted waters and in particular in shallow waters are not provided. When defining the ship's speed in restricted sea areas (confined waters), verbal (descriptive) speed indicators (e.g. critical, boundary, achievable, recommended, optimal, best possible etc.) are used that are not always correct and clearly defined.

According to voyage instructions and charter party requirements, every vessel shall undertake her passage at sea at the 'best possible speed', weather and safe navigation permitting, unless otherwise required.

According to the COLREG (International Rules and Regulations for Prevention of Collisions at Sea) guidelines of the Land Control Services and Movement Organizations (including pilot services and vessel traffic systems VTS), the recommendations of local maritime administrations, ship owners' guidelines and the rules of so-called good sea practice, the ship should always move at a 'safe speed'.

However, a safe speed understood according to the provisions of COLREG is not the same as the safe speed set according to the rules of so-called good maritime practice $[11,18,19]$.

In fact, safe speed in the understanding of COLREG applies only to the speed that allows collision-free operation of the ship with respect to objects located on the water surface, and 
not objects located under water. In addition, these regulations do not specify what should be understood by the term 'safe speed', and what should be considered as the value of that safe speed and what is a dangerous speed.

The selection of the appropriate value of the ship's speed and the trajectory of the ship's movement in restricted sea areas, and especially in shallow waters, navigational channels or sharp bends of the fairway, is left in the hands of the person conning the ship (usually the captain) and the rules of so-called 'good seamanship' or 'maritime practice', while the very concept of 'good seamanship', although it is widely used and used in the provisions of the COLREG regulation, is still not clearly defined.

Another point is term 'ship's domain'. The ship's domain in maritime terminology $[4,6,7,12,13,14,22,23,24]$ is defined as the area around a vessel which is indispensable for maintaining the safety of navigation. According to the definition of the ship's domain, every ship will be safe (in the navigational sense) as long as she is the exclusive object that can generate danger within her domain $[18,19]$. This means that the appearance of any navigational obstacle (intruder) within the ship's domain (its 'exclusivity' area) will dramatically increase the navigational risk and may result in an inevitable collision. The ship's domain will therefore determine a certain area (two-dimensional domain) or some part of space (three-dimensional domain) around the ship, in which to graphically assess the navigational safety of the ship and determine its navigational risk.

The ship's domain as a measurement of a ship's safety has been well studied since it was proposed. Although there are many ship's domains with different shapes $[4,6,12,19,24]$ and sizes obtained by the method of statistical analysis [4, $6,7]$ and artificial intelligence $[13,22,23,24]$, most of these are not objective domains that can ensure the ship's safety by avoiding collisions because most of the models take into account the navigator's subjective psychological factors.

Domains are mainly specific to open $[6,14]$ or restricted waters $[12,22,23]$ and cannot be used for ships in different waters. Domains for restricted sea areas used in open waters are too conservative, while the domains for open waters applied to restricted waters will also not be suitable for the conditions of restricted waters. Meanwhile, the ship's domain even in the same kind of water can differ with differences in the water environment, and an individual ship's domain on a certain kind of water cannot represent the ship's domain for this entire class of ship.

As a result of these analyses, the author suggests the use of a simplified three-dimensional model of the ship's domain $[18,19]$, in which the selection of the optimal speed of the ship should be considered depending on the potential threats detected in relation to its three axes of shading (X, Y, Z), where:

$V_{X}=$ is the safe speed due to the braking distance (stopping the ship at the appropriate time) to avoid collision, taking into account the need to retain the manoeuvrability of the ship, and in particular its turning ability. $V_{X}$ depends on the length of the vessel's domain $S D_{L}$,
$V_{Y}=$ is the safe speed due to external disturbances and restrictions on the water lane (fairway), taking into account the need to maintain the manoeuvrability of the ship and in particular its course stability. $V_{Y}$ depends on the width of the vessel's domain $S D_{W}$,

$V_{Z}=$ is the safe speed due to the limited value of the underkeel clearance (UKC) and/or over-head clearance (OHC), considering the maximum value of the ship's squat effect, the ship's draft and air draft, UKC and OHC. $V_{Z}$ depends on the depth $S D_{D}$ and height $S D_{H}$ of the ship's domain.

From a practical point of view, determining the optimal speed of the ship is required in particular due to the settlement of the ship (ship's squat) when manoeuvring on shallow water $\left(V_{Z}\right)$ and in addition also when manoeuvring on restricted waters where navigational obstacles are arranged in the directions ahead of the ship's bow $\left(V_{X F}\right)$ on the ship's port $\left(V_{Y P}\right)$ and starboard side $\left(V_{Y S}\right)$.

In this paper, the study will focus on determining the ship's optimal safe speed $V_{Z D}$ in shallow waters based on the analysis of a 3-D model of the ship's domain parameters in the OZ plane, and in particular the ship's domain depth parameter $S D_{D}$.

\section{METHODOLOGY FOR DETERMINING SHIP'S OPTIMAL SAFE SPEED $V_{Z D}$ BY MEANS OF SHIP'S DOMAIN DEPTH $S D_{D}$}

For selection of the ship's domain depth $S D_{D}$ we will use the author's simplified 3-D model of the ship's domain presented in his monograph [19].

Determining the ship's domain depth $\left(S D_{D}\right)$ in practice amounts to determining the safety depth (SD) parameter required in ECDIS for the ship's safe passage through shallow waters [17].

The safety depth (SD) is a value that serves to detect the depths that are a danger to navigation. A depth equal to or less than the safety depth is highlighted on the ENC chart in bold type when the display of the spot sounding is turned on. This alerts the user to know the depths that are insufficient for the vessel to safely pass over. Additionally, if any extra allowance of depth is required due to the local port or berth requirements, the same should be included in the calculation of the safety depth (SD), ship's domain depth $\left(S D_{D}\right)$, safety contour (SC) and under-keel clearance (UKC).

The safety contour (SC) value is calculated considering the safety depth and allowing for the category zone of confidence (CATZOC) displayed on an electronic navigational chart (ENC); (safety contour = safety depth + CATZOC). ECDIS selects and highlights the default safety contour, which is equal to or deeper than the safety contour value selected by the user $[17,19]$. The safety contour on the ENC display will default to the next deeper contour if the depth contour of the set value is not available in the displayed ENC source data. The safety contour marks the division between navigable (safe) and non-navigable (unsafe) water. During route planning, an 
indication will be made if the route is planned to cross the ship's safety contour. At the time of route monitoring, ECDIS should give an alarm if, within a specified time set by the navigator, the ship is likely to cross the safety contour [17].

One of the main factors needed to estimate the ship's domain depth $\left(S D_{D}\right)$ equated to the safety depth $(S C)$ is the ship's vertical reserve for squat $\left(R_{\text {squat }}\right)$. The ship's squat is an increase of body sinkage and a change of trim due to the ship's movement through water $[1,2,3,5,11,25]$. Squat depends mainly on the water speed on the side and under the keel clearance (UKC).

The under-keel clearance (UKC) means the minimum clearance available between the deepest point on the vessel and the bottom in still water.

$$
U K C=\left(h_{C D}+\text { Tide }\right)-T_{\max } \quad[\mathrm{m}]
$$

where:

$U K C=$ Under-keel clearance $[\mathrm{m}]$,

$h_{C D}=$ Charted water depth $[\mathrm{m}]$,

Tide $=$ Height of tide $[\mathrm{m}]$,

$T_{\max }=$ Static deep ship's draft.

For squat and UKC calculation, the user should always use the form designated for his vessel and accepted by the company [19], otherwise the estimated risk indicator $\left(\mathrm{R}_{\mathrm{ND}}\right)$ may not be adequate for the ship.

In US waters, we should also be guided by US Coast Guard Publication 33 CFR 157.455. When calculating the dynamic $\mathrm{UKC}$, one must use the latest depth information from the port agent. It is vital to remember that at many dry-bulk cargo berths, due to the falling ore or coal, the depth along the dock wall may be considerably smaller than the one denoted on the official charts. In addition, one must also comply with the local UKC requirements or more stringent charterers' instructions. Generally, as a rule of thumb and good seamanship $[11,19]$, one must ensure that the following UKC requirements are fulfilled:

In port, a UKC not less than $0.60 \mathrm{~m}$ is required. This rule applies when navigating within a port (including the fairways, channels, canals), secured to a berth or any other installation such as SPM (single-point mooring) or CBM (conventional buoy mooring) systems, except under special circumstances.

When navigating at sea (except in very special circumstances), the UKC must never be less than:

- In confined (restricted) waters and port approaches, a minimum dynamic UKC of $10 \%$ of the deepest static draft,

- In open coastal waters, a minimum dynamic UKC of $20 \%$ of the deepest static draft,

- On an ocean passage, one must keep clear of localised shallow areas and as far as possible in depths over $50 \mathrm{~m}$.

- When transiting the Malacca and Singapore Straits when the draft is more than $15 \mathrm{~m}$ or on a tanker greater than 150000 MT DWT, a minimum UKC of $3.5 \mathrm{~m}$ must be ensured.
Special circumstances: If the voyage orders specify a draft or cargo nomination that, after the Master's best efforts, will result in a UKC less than the ship's operator limits, the Master must notify the operator's technical and commercial operations departments. A UKC limit less than the limits mentioned above may be permitted if in compliance with the local regulations, rules or recommendations by the relevant authorities and if it has been confirmed that other vessels of similar build, size, draft and speed have already established the safety of such a transit under prevailing environmental conditions [19].

Depending on the circumstances of the case, the following conditions may need to be checked with the relevant authorities, agents or terminal:

- Will the vessel be in calm sheltered waters under a controlled speed?

- Will it be possible to verify the ship's draft accurately?

- Are there locks or dock sills to cross?

- Can the latest sounding chart and information for the berth, including the nature of the sea bottom, be obtained directly from the local authorities or terminals well before arrival or lightering?

- Can berthing at discharge ports and unberthing at load ports be carried out during high water only? At discharge ports, plan to start cargo operations well before the low water.

If the conditions set by the shipowner and/or charterer of the ship cannot be met and the vessel is required to breach the UKC limits, the Master must generate temporary deviations from the company procedures. If in doubt, he/she must abort the passage or vacate the berth, keep all parties informed and maintain suitable records. In addition, if it is ever suspected that the vessel has touched the bottom, it is important to notify the pilot and make the appropriate logbook entries, including the date, time and position, and the company management team must be notified and the incident investigated to check for damage.

The squat effect occurs at all times when a vessel is making headway through the water, or secured alongside a berth with a flow of water passing around the hull, but the amplified effects experienced in confined and shallow waters have a profound effect on the safety of the vessel.

The squat effect is caused when buoyancy or the hull pressure is reduced and the vessel is forced deeper into the water to support its weight [11]. Generally, as a rule of thumb the squat increases where a channel width is less than 8.25 times the beam, combined with a static UKC of less than $20 \%$ of the draft $[19,25]$.

The squat of the vessel is an approximation of additional immersion based on the following: the vessel's draft, speed and block coefficient; the width and shape of the channel and the available depth.

Squat should be calculated using the speed through the water rather than the speed over the ground [19]. Reducing the speed is the best means to reduce a vessel's dynamic draft and is an essential consideration for passage planning. Also, on full form ships (such as tankers), the squat effect leads to 
an increase of the forward draft and tends to trim a vessel by the head.

The tidal stream and current need only be considered in calculating squat when a vessel is secured alongside a berth. Since the main factor in calculating squat is speed through the water, the tidal stream and current will not affect the amount of squat a vessel experiences when underway and making way. It must also be noted that any calculation made for squat is approximate and for guidance only. Due to the inherent inaccuracy of the information affecting it, extreme caution and judgment should be exercised in calculating and applying squat, keeping potential error on the safe side $[2,11,15,19,25]$.

The squat effect equals the total parallel body sink plus any subsequent trimming of the vessel $[19,25]$. The water flow will follow different patterns in relation to the different shapes of the forward and aft hull. The aft hull is shaped to give a stable inflow to the propeller, while the forward hull is designed for other objectives. Differences in the flow pattern influence the hull pressure or buoyancy. Fluctuations in the buoyancy on the forward and aft hulls lead to trimming of the vessel. In general, the following applies [11, 19, 25]:

- Block coefficient $C_{B}>0.7$ - vessel trims forward;

- Block coefficient $C_{B}=0.7$ - no apparent trim;

- Block coefficient $C_{B}<0.7$ - vessel trims aft.

For vessels with a block coefficient $C_{B}>0.7$, the application of squat is based on the following: $75 \%$ of the squat is an increase in body sinkage and $25 \%$ is a change in trim by the head $[19,25]$.

While navigating in confined (restricted) waters, other conditions that should be considered along with squat include turning, which causes listing and increased drafts, depending on the beam of the vessel. Also, the steering characteristics and course-keeping ability can be affected when the UKC diminishes (that is, the turning circle radius may increase).

In such case the required speed $V_{Z D}$ can be defined as the ship's safe and/or optimal speed due to the limited value of the under-keel clearance, taking into account the maximum value of the ship's squat, ship's draft and UKC. $V_{Z D}$ depends on the ship's domain depth $S D_{D}$.

When studying the professional publications, there are many methods for estimating the ship's squat (e.g. [1-3, 9-11, $15,20,25])$ when proceeding in a restricted sea area across shallow water. In practice, for ship's domain depth $\left(S D_{D}\right)$ calculations purposes, the different criteria and formulae should be considered where no computer-based program is available.

Similarly, the final formulae for the ship's bordered optimal safe speed $V_{Z D}$ due to the limited value of the required under-keel clearance $\left(V_{Z D}\right.$ dependent on $\left.S D_{D}\right)$, obtained after transforming the formulae presented below for the ship's domain depth $S D_{D}$ relative to the unknown speed value $V$, with the limitation: depth of the basin $h>T_{\text {max }}$ aligned to desired ship's domain depth $h=S D_{D}, S D_{D} \geq n \cdot T_{\max }+k \cdot h_{\rho}$, will then take a form depending on the calculation method used.
- Using precisely the method by C.B. Barrass [1, 11] for estimating the ship's squat, with the limitation $0.5 \leq \mathrm{C}_{\mathrm{B}}$ $\leq 0.9 ; 0 \leq \mathrm{t} / \mathrm{L} \leq 0.005 ; 1.1 \leq \mathrm{h} / \mathrm{T} \leq 1.4$ :

$$
\begin{aligned}
S D_{D} & =n \cdot T_{\text {max }}+\frac{m \cdot C_{B}}{30} \cdot\left(\frac{B \cdot T}{b \cdot h-B \cdot T}\right)^{\frac{2}{3}} \cdot V^{2.08}+[\mathrm{m}] \\
k \cdot h_{f} & \left(\frac{30 \cdot\left(S D_{D}-n \cdot T_{\max }-k \cdot h_{f}\right)}{m \cdot C_{B} \cdot\left(\frac{B \cdot T}{b \cdot h-B \cdot T}\right)^{\frac{2}{3}}}\right)^{\frac{25}{52}}[\mathrm{kn}]
\end{aligned}
$$

- Using the simplified Barrass [1] method for estimating the ship's squat in shallow water, with the limitation: 1.1 $\leq \mathrm{h} / \mathrm{T} \leq 1.2$ :

$$
\left.\begin{array}{c}
S D_{D}=n \cdot T_{\max }+m \cdot\left(0.01 \cdot C_{B} \cdot V^{2}\right)+k \\
\cdot h_{f}
\end{array}\right]
$$

- Using the simplified Barrass [1] method for estimating the ship's squat in a narrow channel, with the limitation: $0.06 \leq \frac{B \cdot T}{b \cdot h} \leq 0.3$ :

$$
\begin{gathered}
S D_{D}=n \cdot T_{\max }+m \cdot\left(0.02 \cdot C_{B} \cdot V^{2}\right)+k \cdot[\mathrm{m}] \\
V_{Z D}=\sqrt{\frac{S D_{D}-n \cdot T_{\max }-k \cdot h_{f}}{0.02 \cdot m \cdot C_{B}}} \quad[\mathrm{kn}]
\end{gathered}
$$

- Using the Eryuzlu \& Hausser method (based on [11]) for estimating the ship's squat in a sea area, with the limitation: $\mathrm{C}_{\mathrm{B}} \geq 0.7 ; 1.08 \leq \frac{\hbar}{T} \leq 2.78$ :

$$
\begin{aligned}
& S D_{D}=n \cdot T_{\max }+m \\
& \cdot\left(0.113 \cdot B \cdot\left(\frac{h}{T}\right)^{-0.27}\right. \\
& \left.\cdot\left(\frac{0.514 \cdot V}{\sqrt{g \cdot h}}\right)^{1.8}\right)+k \cdot h_{f} \\
& V_{Z D} \\
& =6.533 \sqrt{g \cdot h} \\
& \cdot\left(\frac{h}{T}\right)^{0.15} \cdot\left(\frac{S D_{D}-n \cdot T_{\max }-k \cdot h_{f}}{m \cdot B}\right)^{\frac{5}{9}}
\end{aligned}
$$

- Using the Soukhomel \& Zass method (based on [11]) for estimating the ship's squat in shallow unrestricted water, with the limitation: $3.5 \leq \frac{L}{B} \leq 9$ : 


$$
\begin{array}{r}
S D_{D}=n \cdot T_{\text {max }}+m \cdot l \cdot 0.049047542 \cdot V^{2} \\
\cdot \sqrt{\frac{T}{h} \cdot\left(\frac{L}{B}\right)^{-1.11}+k \cdot h_{f}} \\
V_{Z D}=4.5154 \cdot \sqrt{\frac{S D_{D}-n \cdot T_{\max }-k \cdot h_{f}}{m \cdot l \cdot \sqrt{\frac{T}{h}} \cdot\left(\frac{L}{B}\right)^{-1,11}}}
\end{array}
$$

where:

$S D_{D}=$ Ship's domain depth, $[\mathrm{m}]$
$V=$ Ship's speed through the water, $[\mathrm{kn}]$

$V_{Z D}=$ Ship's safe speed $V_{Z}$ due to the limited value of the required under-keel clearance and ship's domain depth $S D_{D}$, [kn],

$R_{\text {squat }}=$ Vertical reserve for ship's squat effect, $[\mathrm{m}]$,

$B=$ Ship's width, $[\mathrm{m}]$,

$L=$ Ship's length, $[\mathrm{m}]$,

$T=T_{\max }=$ Ship's maximum draught (static), $T=T_{\max }$, $[\mathrm{m}]$,

$C_{B}=$ Ship's block coefficient,

$h=$ The depth of sea area, $[\mathrm{m}]$,

$b=$ The width of sea area, $[\mathrm{m}]$,

$h_{f}=$ Wave height (swell), [m],

$g=$ The standard gravity of the Earth, the net acceleration that is imparted to objects due to the combined effect of gravitation and the centrifugal force from the Earth>s rotation, $g=9.81 \frac{\mathrm{m}}{\mathrm{s}^{2}}$.

$n=$ Numeric coefficient (factor) dependent on type of sea areas and sea bottoms based on author's own research (2000) regarding determining ship's static vertical navigational reserve.

$m=$ Numeric factor $(1.0 \leq \mathrm{m} \leq 2.0)$ correcting the function values $R_{\text {squat }}=f\left(m, V, B, L, T, C_{B}, h, b\right)$ depending on the navigational situation in which the ship finds itself (e.g. overtaking, passing, navigating over inequalities, navigation in ice, silt) and discrepancies in the ship's parameters and parameters of the basin from the parameters adopted in the method of calculating the ship's squat

$k=$ Numeric coefficient (factor $k$ ) dependent on ship's particulars (speed $=V$, width $=B$, length $=L$, block coefficient $=C_{B}$ ) and waves characteristics (length $=\lambda$, height $=h_{f}$ and wave attack angle $=q$ ), which determines the ship's dynamic vertical navigational reserve $R_{d}$ on sea waves.

$l=$ Numeric coefficient (factor): $1.1 \leq 1 \leq 1.5$, dependent on ship's length $L$ ad ship's width $B$.

Tab. 1. Relation between numeral coefficient (factor) $l$ and ship's length $L$ and width $B$.

Source: Based on author's own research. [19]

\begin{tabular}{|l|c|c|c|}
\hline$L$ to $B$ ratio & $7 \leq \frac{L}{B} \leq 9$ & $5 \leq \frac{L}{B} \leq 7$ & $3.5 \leq \frac{L}{B} \leq 5$ \\
\hline Factor $l$ value & 1.10 & 1.25 & 1.50 \\
\hline
\end{tabular}

Tab. 2. Numeral coefficient (factor $n$ ) dependent on type of sea areas and sea bottoms, which determines ship's static vertical navigational reserve for required UKC based on author's own research

\begin{tabular}{|c|l|l|}
\hline $\mathrm{n}$ & \multicolumn{1}{|c|}{ Type of sea area } & Type of sea bottom \\
\hline 1.1 & Port area, internal and inshore channels & Mud \\
\hline 1.15 & $\begin{array}{l}\text { Road, approaching channels to the port, } \\
\text { inshore area }\end{array}$ & Sand \\
\hline$>1.2$ & Open sea & Rock, stone \\
\hline
\end{tabular}

Tab. 3. The value of $m$ numeric factor $(1.0 \leq m \leq 2.0)$ correcting the function values $R_{\text {squat }}=f\left(m, V, B, L, T, C_{B}, h, b\right)$ depending on the navigational situation in which the ship finds itself (e.g. overtaking, passing, navigating over inequalities, navigation in ice, silt) and discrepancies in the ship's parameters and parameters of the basin from the

\begin{tabular}{|c|c|c|}
\hline$m$ & Parameters of the ship & $\begin{array}{l}\text { Parameters of the channel or } \\
\text { other navigable waters }\end{array}$ \\
\hline 1.0 & $\begin{array}{l}\text { Compliant with the accepted } \\
\text { method of calculation, or } \\
\text { incompatible but less stringent, } \\
\text { for example, slender ships and } \\
\text { slower ships accepted in the } \\
\text { calculation method }\end{array}$ & $\begin{array}{l}\text { Compliant with the accepted } \\
\text { method of calculation or } \\
\text { incompatible but less stringent, } \\
\text { e.g. sea area parameters with } \\
\text { navigation waters higher than } \\
\text { those recommended in the } \\
\text { method }(b, h)\end{array}$ \\
\hline 1.5 & $\begin{array}{l}\text { Not compatible with the } \\
\text { calculation method used, e.g. } \\
\text { ships more full-featured than } \\
\text { those recommended in the } \\
\text { method }\end{array}$ & $\begin{array}{l}\text { Compliant with the accepted } \\
\text { method of calculation or } \\
\text { incompatible but less stringent } \\
\text { e.g. sea area parameters higher } \\
\text { than those recommended in } \\
\text { the method }(b, h)\end{array}$ \\
\hline 1.5 & $\begin{array}{l}\text { Compliant with the accepted } \\
\text { method of calculation, or } \\
\text { incompatible but less stringent, } \\
\text { for example, slender ships and } \\
\text { slower ships accepted in the } \\
\text { calculation method }\end{array}$ & $\begin{array}{l}\text { Not compliant with the } \\
\text { calculation method (sea } \\
\text { area parameters with } \\
\text { navigation water lower than } \\
\text { recommended), off-axis } \\
\text { navigation, overtaking or } \\
\text { passing in the channel }\end{array}$ \\
\hline 2.0 & $\begin{array}{l}\text { Not compatible with the } \\
\text { calculation method used, e.g. } \\
\text { ships more full-featured than } \\
\text { those recommended in the } \\
\text { method }\end{array}$ & $\begin{array}{l}\text { Not compliant with the } \\
\text { calculation method (sea } \\
\text { area parameters with } \\
\text { navigation water lower than } \\
\text { recommended), off-axis } \\
\text { navigation, overtaking or } \\
\text { passing in the channel }\end{array}$ \\
\hline
\end{tabular}
parameters adopted in the method of calculating the ship's squat. Source: Author's own research

Tab. 4. Numeric coefficient (factor $k$ ) dependent on ship's particulars: $V, B$, $L, C B$ and waves characteristics: $\lambda, h_{f}$ and $q$, which determines ship's dynamic vertical navigational reserve $R_{d}$ on sea waves based on author's own research

\begin{tabular}{|c|l|l|}
\hline$k$ & $\begin{array}{c}\text { Sea wave direction equal to } \\
\text { ship's heading line (waves from } \\
\text { ahead or astern of the vessel } \\
\left.\mathrm{q} \approx 000^{\circ} \text { or } 180^{\circ}\right)\end{array}$ & $\begin{array}{c}\text { Sea wave direction } \\
\text { perpendicular to ship's } \\
\text { heading (waves from the port } \\
\text { or starboard beam of the } \\
\left.\text { vessel, } \mathrm{q} \approx 090^{\circ}\right)\end{array}$ \\
\hline 0.33 & When: $V=0$ and $\mathrm{L}>\lambda$ & When: $V=0 \& \mathrm{~B}>0.5 \cdot \lambda$ \\
\hline 0.66 & When: $V \geq 10 \mathrm{kn}$ and $\mathrm{L}>\lambda$ & When: $V \geq 10 \mathrm{kn} \& \mathrm{~B}>0.5 \cdot \lambda$ \\
\hline 0.75 & When: $V<10 \mathrm{kn}$ and $\mathrm{L}<0.5 \cdot \lambda$ & When: $V<10 \mathrm{kn} \& \mathrm{~B}<0.5 \cdot \lambda$ \\
\hline 1.00 & When: $V \geq 10 \mathrm{kn}$ and $\mathrm{L}<0.5 \cdot \lambda$ & When: $V \geq 10 \mathrm{kn} \& \mathrm{~B}<0.5 \cdot \lambda$ \\
\hline
\end{tabular}




\section{RESULTS FOR DETERMINING THE SHIP'S OPTIMAL SAFE SPEED $V_{Z D}$ ON SHALLOW WATERS AND NAVIGATIONAL CHANNELS}

Tables 5 and 6 depict examples of the bordered (optimal) ship's safe speed $V_{Z D}$ calculated according to the above formulas, for VLCC Warta and ULCC Blue Lady manoeuvring in a navigational channel inside a port limit area with the following parameters: width $b=150 \mathrm{~m}$, assumed depth of the basin $h>T_{\max }$ aligned to the desired ship's domain depth $\mathrm{h}=\mathrm{SD}_{\mathrm{D}}$ (with the limitation $S D_{D} \geq n \cdot T_{\max }+k \cdot h_{f}$ ), measured at calm sea with wave height $h_{f}=0 \mathrm{~m}$.

For comparison, see also Tables 7 and 8 with the results of calculations made for the aforementioned ships moving in shallow waters with the following parameters: width $b=350 \mathrm{~m}$, assumed depth of the basin $h>T_{\max }$ aligned to the desired ship's domain depth $h=S D_{D}$ (with the limitation $\left.S D_{D} \geq n \cdot T_{\max }+k \cdot h_{f}\right)$, measured at moderate sea with wave height $\mathrm{h}_{\mathrm{f}}=1.5 \mathrm{~m}$ and wave length $\lambda \approx 200 \mathrm{~m}$ (factor $\mathrm{k}=0.66$ ).

Tab. 5. Sample values of the bordered safe speed $V_{Z D}$ calculated for VLCC Warta manoeuvring in navigational channel inside port area with the following parameters: width $b=150 \mathrm{~m}$, assumed depth of the basin $h>T_{\max }$ aligned to desired ship's domain depth $h=S D_{D}$, navigational risk $R N D \approx 0$, with limitation with the limitation $S D_{D}>n \cdot T_{\max }+k \cdot h_{\rho}$ measured at calm sea with wave height $h_{f}=0 \mathrm{~m}$. Source: Author's own research Apr. 2019

\begin{tabular}{|c|c|c|c|c|c|c|}
\hline 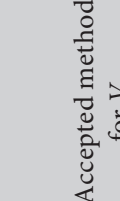 & 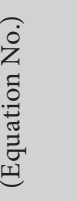 & \multicolumn{5}{|c|}{$\begin{array}{c}\text { VLCC WARTA } \\
D=176967 \mathrm{t}, \mathrm{L}=293 \mathrm{~m}, \mathrm{~B}=48.0 \mathrm{~m} \\
T=15.5 \mathrm{~m}, \mathrm{C}_{B}=0.844, V_{\max }=15 \mathrm{kn}, P=29000 \mathrm{HP}, \\
122 \mathrm{rpm}, H_{H P}=55 \mathrm{~m}, \\
n=1.1, m=1.0, k=0.33, l=1.25\end{array}$} \\
\hline \multicolumn{2}{|c|}{ Desirable $S D_{D}=h$} & $\begin{array}{l}17.1 \\
{[\mathrm{~m}]}\end{array}$ & $\begin{array}{l}17.5 \\
{[\mathrm{~m}]}\end{array}$ & $\begin{array}{l}18.0 \\
{[\mathrm{~m}]}\end{array}$ & $\begin{array}{l}18.5 \\
{[\mathrm{~m}]}\end{array}$ & $\begin{array}{l}19.0 \\
{[\mathrm{~m}]}\end{array}$ \\
\hline \multirow{5}{*}{ 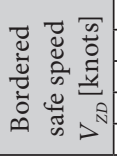 } & (3) & 1.76 & 5.10 & 7.40 & 9.18 & 10.71 \\
\hline & (5) & 2.43 & 7.30 & 10.61 & 13.11 & 15.20 \\
\hline & (7) & 1.72 & 5.16 & 7.50 & 9.27 & 10.75 \\
\hline & (9) & 1.89 & 6.51 & 10.04 & 12.93 & 15.51 \\
\hline & (11) & 2.53 & 7.62 & 11.15 & 13.87 & 16.20 \\
\hline
\end{tabular}

Tab. 6. Sample values of the bordered safe speed $V_{Z D}$ calculated for ULCC Blue Lady manoeuvring in navigational channel inside port area with the following parameters: width $b=150 \mathrm{~m}$, assumed depth of the basin $h>T_{\max }$ aligned to desired ship's domain depth $h=S D_{D^{\prime}}$ navigational risk $R_{N D} \approx 0$, with limitation $S D_{D}>n \cdot T_{\max }+k \cdot h_{f}$ measured at calm sea with wave height $h f=0 \mathrm{~m}$.

Source: Author's own research Apr. 2019

\begin{tabular}{|c|c|c|c|c|c|c|}
\hline \multirow{2}{*}{\multicolumn{2}{|c|}{ 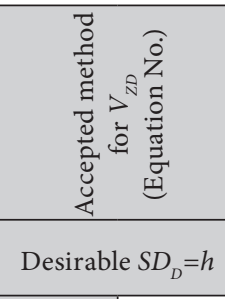 }} & \multicolumn{5}{|c|}{$\begin{array}{c}\text { ULCC BLUE LADY } \\
D=323660 t, L=331 \mathrm{~m}, B=57.0 \mathrm{~m}, \\
T=20.6 \mathrm{~m}, C_{B}=0.790 ; V_{\text {max }}=15 \mathrm{kn}, P=27000 \mathrm{HP}, 85 \\
\mathrm{rpm}, H_{H P}=75 \mathrm{~m}, \\
n=1.1, m=1.0, k=0.33, l=1.25\end{array}$} \\
\hline & & $\begin{array}{l}22.7 \\
{[\mathrm{~m}]}\end{array}$ & $\begin{array}{r}23.0 \\
{[\mathrm{~m}]}\end{array}$ & $\begin{array}{r}23.5 \\
{[\mathrm{~m}]} \\
\end{array}$ & $\begin{array}{r}24.0 \\
{[\mathrm{~m}]} \\
\end{array}$ & $\begin{array}{l}24.5 \\
{[\mathrm{~m}]} \\
\end{array}$ \\
\hline \multirow{5}{*}{ 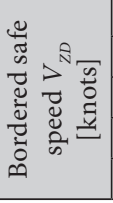 } & (3) & 1.50 & 4.23 & 6.60 & 8.35 & 9.82 \\
\hline & (5) & 2.25 & 6.56 & 10.31 & 13.02 & 15.26 \\
\hline & $(7)$ & 1.59 & 4.64 & 7.29 & 9.21 & 10.79 \\
\hline & (9) & 1.75 & 5.80 & 9.72 & 12.77 & 15.43 \\
\hline & (11) & 2.20 & 6.43 & 10.15 & 12.89 & 15.19 \\
\hline
\end{tabular}

Note: The author chose the ships VLCC Warta and ULCC Blue Lady for this research, taking into account the fact that models of these ships are also available and used for research in the Foundation for Safety of Navigation and Environment Protection Ship Handling Research and Training Centre, Iława-Poland.

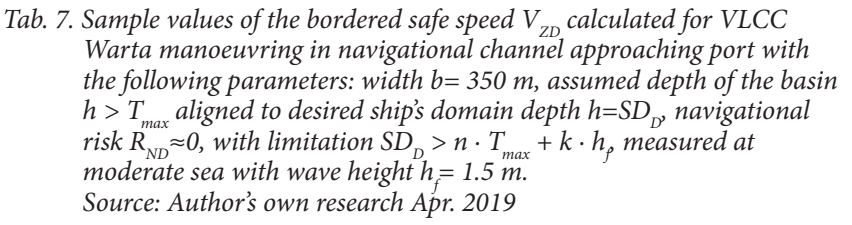
Warta manoeuvring in navigational channel approaching port with the following parameters: width $b=350 \mathrm{~m}$, assumed depth of the basin $h>T_{\max }$ aligned to desired ship's domain depth $h=S D_{D^{\prime}}$ navigational risk $R_{N D}^{\max } \approx 0$, with limitation $S D_{D}>n \cdot T_{\max }+k \cdot h_{\rho}$ measured at moderate sea with wave height $h_{f}=1.5 \mathrm{~m}$.

Source: Author's own research Apr. 2019

\begin{tabular}{|c|c|c|c|c|c|c|}
\hline \multirow{2}{*}{\multicolumn{2}{|c|}{ 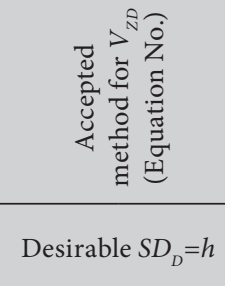 }} & \multicolumn{5}{|c|}{$\begin{array}{c}\text { VLCC WARTA } \\
\begin{array}{c}D=176967 t, L=293 \mathrm{~m}, B=48.0 \mathrm{~m}, \mathrm{~T}=15.5 \mathrm{~m}, \\
C_{B}=0.844, V_{\text {max }}=15 \mathrm{kn}, P=29000 \mathrm{HP}, 122 \mathrm{rpm}, \\
H_{H P}=55 \mathrm{~m}, \\
n=1.15, m=1.0, k=0.66, l=1.25\end{array}\end{array}$} \\
\hline & & $\begin{array}{l}18.9 \\
{[\mathrm{~m}]}\end{array}$ & $\begin{array}{l}19.0 \\
{[\mathrm{~m}]}\end{array}$ & $\begin{array}{l}19.5 \\
{[\mathrm{~m}]}\end{array}$ & $\begin{array}{l}20.0 \\
{[\mathrm{~m}]}\end{array}$ & $\begin{array}{l}20.5 \\
{[\mathrm{~m}]}\end{array}$ \\
\hline \multirow{5}{*}{ 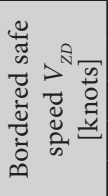 } & (3) & 3.30 & 4.80 & 9.10 & 11.95 & 14.28 \\
\hline & (5) & 3.17 & 4.68 & 9.01 & 11.85 & 14.13 \\
\hline & (7) & 2.24 & 3.31 & 6.37 & 8.38 & 9.99 \\
\hline & (9) & 2.71 & 4.19 & 8.82 & 12.16 & 15.03 \\
\hline & (11) & 3.38 & 4.99 & 9.66 & 12.79 & 15.34 \\
\hline
\end{tabular}

Tab. 8. Sample values of the bordered safe speed $V_{\mathrm{ZD}}$ calculated for ULCC Blue Lady manoeuvring in navigational channel approaching port with the following parameters: width $b=350 \mathrm{~m}$, assumed depth of the basin $h>T_{\max }$ aligned to desired ship's domain depth $h=S D D$, navigational risk $R_{N D} \approx 0$, with limitation $S D_{D}>n \cdot T_{\max }+k \cdot h_{\rho}$ measured at moderate sea with wave height $h_{f}=1.5 \mathrm{~m}$. Source: Author's own research Apr. 2019

\begin{tabular}{|c|c|c|c|c|c|c|}
\hline \multirow{2}{*}{\multicolumn{2}{|c|}{ 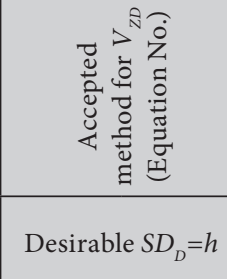 }} & \multicolumn{5}{|c|}{$\begin{array}{c}\text { ULCC BLUE LADY } \\
D=323660 \mathrm{t}, L=331 \mathrm{~m}, \mathrm{~B}=57.0 \mathrm{~m}, \\
T=20.6 \mathrm{~m}, \mathrm{C}_{B}=0.790 ; V_{\max }=15 \mathrm{kn}, P=27000 \mathrm{HP}, \\
85 \mathrm{rpm}, H_{H P}=75 \mathrm{~m}, \\
n=1.15, m=1.0, k=0.66, l=1.25\end{array}$} \\
\hline & & $\begin{array}{c}24.7 \\
{[\mathrm{~m}]}\end{array}$ & $\begin{array}{l}25.0 \\
{[\mathrm{~m}]}\end{array}$ & $\begin{array}{c}25.5 \\
{[\mathrm{~m}]}\end{array}$ & $\begin{array}{c}26.0 \\
{[\mathrm{~m}]}\end{array}$ & $\begin{array}{c}26.5 \\
{[\mathrm{~m}]}\end{array}$ \\
\hline \multirow{5}{*}{ 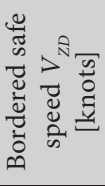 } & (3) & 1.59 & 6.04 & 9.56 & 12.11 & 14.23 \\
\hline & (5) & 1.59 & 6.36 & 10.19 & 12.93 & 15.18 \\
\hline & (7) & 1.13 & 4.50 & 7.20 & 9.14 & 10.73 \\
\hline & (9) & 1.26 & 5.92 & 10.11 & 13.34 & 16.14 \\
\hline & (11) & 1.59 & 6.37 & 10.24 & 13.06 & 15.40 \\
\hline
\end{tabular}

\section{NAVIGATIONAL RISK FACTOR}

According to the author's own research (from 2000 to 2020) on definition of the ship's domain, every ship will be safe (in the navigational meaning) as long as it is the exclusive object that can generate danger within its domain. With reference to a vertical plane $\mathrm{OZ}$ of the three-dimensional co-ordinates XYZ established down from the central point of the local ship's reference system, one can state unambiguously that every ship will remain safe as long the value of the ship's domain depth $S D_{D}$ is smaller than the real value of the sea depth $h$. Therefore, component $R_{N D}$ of $R_{N}$ can be referred to as the vertical component of the navigational risk, which 
concerns keeping sufficient required under-keel clearance, or risk concerning the under-keel clearance.

$$
R_{N D}=\left\{\begin{array}{ccc}
0 & \text { when } & h>S D_{D} \\
\frac{S D_{D}-h}{S D_{D}-T_{\max }} & \text { when } & T_{\max }<h \leq S D_{D} \\
1 & \text { when } & h \leq T_{\max }
\end{array}\right.
$$

where:

$R_{N D}=$ Numeric factor defining vertical component of the navigational risk $R_{N}$ that concerns keeping sufficient required under-keel clearance,

$S D_{D}=$ Ship's domain depth expressed in metres, [m],

$h=$ Actual water depth, $[\mathrm{m}]$,

$T_{\max }=$ The maximum draft of the vessel, [m].

Formula (12) indicates that the value zero of the navigational risk, deriving from factors (objects), signifies total navigational safety with respect to these factors (objects). Consequently, according to formula (12), the assumption $h>S D_{D}$ can be defined as the guarantee of safe shipping (navigation) with reference to all underwater objects or obstructions immersed at a depth less than $h$. If the sea depth $h$ is less than or equal to the ship's maximum draft $\left(T_{\max }\right)$, that is $h \leq T_{\text {max }}$, according to formula (12) sea passage can be unfeasible or highly risky.

Tab. 9. Relationship between ship speed $V$, domain depth SDD, ship's squat and navigational risk factor RND calculated for VLCC Warta ( $B=48 \mathrm{~m}$, $L=293 \mathrm{~m}, T=15 \mathrm{~m}, C B=0.844$ ) manoeuvring in navigational channel with different speed inside port area with the following parameters: width $b=150 \mathrm{~m}$, assumed depth of the basin $h=1.1 \cdot T_{\text {max }}=16.5 \mathrm{~m}$, wave height $h_{f}=1.0 \mathrm{~m}$, factors: $m=1, n=1.1, k=0.75$.

Source: Author's own research Dec. 2019

\begin{tabular}{|c|c|c|c|c|c|c|c|c|}
\hline $\mathrm{V}$ & 0 & 2 & 4 & 6 & 8 & 10 & 12 & 14 \\
\hline Squat & 0 & 0.07 & 0.28 & 0.65 & 1,17 & 1.87 & 2,73 & 3.76 \\
\hline $\mathrm{SD}_{\mathrm{D}}$ & 17.25 & 17.32 & 17.53 & 17.90 & 18.42 & 19.12 & 19.98 & 21.01 \\
\hline $\mathrm{R}_{\mathrm{ND}}$ & 0.33 & 0.35 & 0.41 & 0.48 & 0.56 & 0.64 & 0.70 & 0.75 \\
\hline
\end{tabular}

Note: For estimating ship's squat the Barrass method [1, 11] has been used, with limitation $0.5 \leq C B \leq 0.9 ; 0 \leq t / L \leq 0.005$; $1.1 \leq h / T \leq 1.4$. For calculating SDD formula (2) has been used and for RND formula (12).

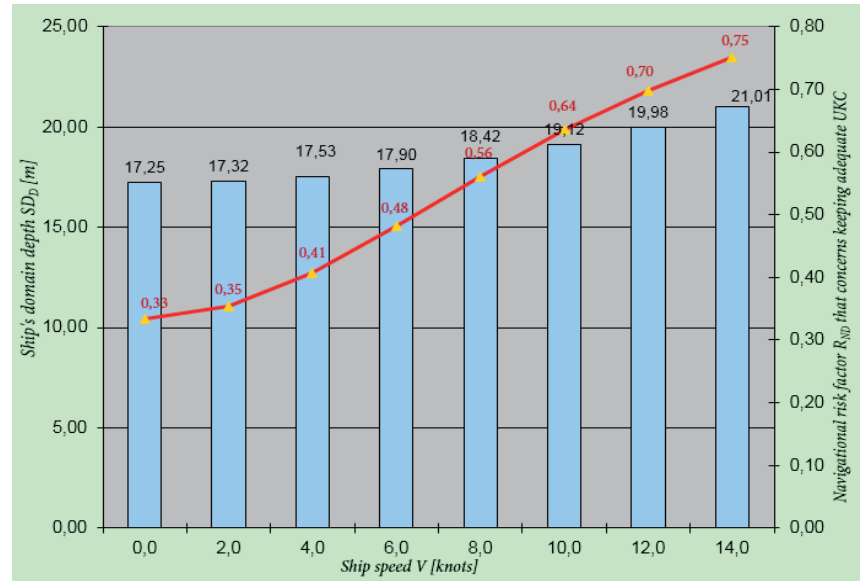

Fig. 1. Relationship between ship speed $V$, domain depth $S D_{D}$ and navigational risk factor $R_{N D}$ calculated for VLCC Warta based on data available in Tab. 9. Source: Author's own research Dec. 2019
In that situation the value of the navigational risk $R_{N D}$ will equal one, and in all probability, it will signify an unquestionable (100\%) risk of collision with some underwater object(s) immersed at a depth less than $h$. Furthermore, we can also say that the value of navigational risk $R_{N D}$ for the sea depth $h$ limited between $T_{\max }$ and $S D_{D}:\left(T_{\max }<h \leq S D_{D}\right)$ will be limited between zero and one $\left(R_{N D} \in[0,1]\right)$.

The relationship between the vessel speed $V$, ship's squat, domain depth $S D_{D}$ and navigational risk factor $R_{N D}$ prepared for VLCC Warta is presented in Table 9 and Fig. 1.

\section{CONCLUSION}

Summing up, it can be stated that, regardless of the voyage option adopted, according to COLREG regulations and the principles of good seamanship, the ship should always move at a safe speed. According to COLREG, what is a safe speed will depend on the vessel and circumstances, bearing in mind that every vessel shall at all times proceed at a safe speed so that it can take proper and effective action to avoid collision and be stopped within a distance appropriate to the prevailing circumstances and conditions. COLREG sets out some factors to be considered by all vessels and vessels with operational radar. However, the unambiguous definition of a safe speed, disregarding the ship's margin of safety determined by the outline of its three-dimensional domain, is too complex an issue, which at the present state of knowledge cannot give us an unambiguous answer as to the specific value of the ship's safe speed when navigating in restricted sea areas.

Practice prescribes that choosing the right ship speed in restricted sea areas on confined waters is a form of compromise between the optimal speed (due to time or fuel consumption) and the safe speed set for the current navigational situation $[9,19]$.

The optimum speed (the right one) will therefore be the speed enabling travel to be made at the right time (fulfilling the contract), and at the same time guaranteeing a constant safety margin (so-called speed reserves) in the event of unpredictable, emergency situations and those resulting from the deployment (position) of navigational obstacles around the ship. As a result, the optimal speed setting will always be reduced to the comparative analysis of individual components of the safe speed: $V_{X}, V_{Y}, V_{Z}$, determined based on the outline of the ship's domain.

From a practical point of view, the initial element for the analysis of the navigational risk in restricted waters (areas restricted by the water depth, air vertical clearance under the bridges and/or width of navigable waters) is the estimation of the ship's domain parameters (her depth $S D_{D}$, height $S D_{H}$, width $S D_{W}$ and length $S D_{L}$ ).

The author's own research $[16,17,18,19]$ proves that these activities (calculations) can be performed on a ship in real time, and their results, if necessary (e.g. for controlling the movement of ships manoeuvring in restricted waters based on the value of their navigational risk indicators), can be 
attached to standard reports e.g. via the ship's Automatic Identification System AIS.

In this way it is shown that, contrary to the accepted practice, modelling the domain of a ship when manoeuvring in restricted waters is also possible. In practice, this means that a thorough analysis of the navigational risk of ships sailing in restricted waters is also possible and may help us choose such conditions (internal and/or external) in which the sea passage will be effective, safe and in line with the needs of the global maritime transportation system, including selection of the optimal safe speed on shallow water.

\section{REFERENCES}

1. Barrass C. B. (1994): Further Discussion on Squat. Seaways, March 1994.

2. Duda D., Norwisz K. (1976): Definition of a ship's safe reserve and under keel clearance. Ship's squat. In Polish: Określenie bezpiecznej rezerwy pod stępką. Osiadanie statku., WSM, Gdynia, Poland.

3. Ferreiro L. D. (1992): The effects of confined water operations on ship performance: A guide for the perplexed. Naval Engineers Journal, November, 1992.

4. Fujii Y. and Tanaka K. (1971): Traffic capacity. Journal of Navigation, 24, 543-552.

5. Gucma S., Jagniszczak I. (1997): Navigation for the master mariner. In Polish: Nawigacja Morska dla Kapitanów, Foka Publisher, Szczecin, Poland.

6. Goodwin E. M. (1975): A statistical study of ship domains. The Journal of Navigation, 28, 328-344.

7. Hansen M. G., Jensen T. K., Lehn-Schiøler T., Melchild K., Rasmussen F. M., Ennemark F. (2013): Empirical ship domain based on AIS data. The Journal of Navigation, 66, 931-940.

8. Hooft J. P. (1969): On the critical speed range of ship in restricted waterways. International Shipbuilding Progress, No 177.

9. Jurdziński M. (1999): Planning the speed of the ship in confined waters. In Polish: Planowanie prędkości statku na wodach ograniczonych, Gdynia, Poland.

10. 10. Millward A. (1990): A preliminary design method for the prediction of squat in shallow water. Marine Technology, Vol.27 (No 1).

11. Nowicki A. (1999): Knowledge about manoeuvring with sea going vessels. In Polish: Wiedza o manewrowaniu statkami morskimi, Trademar Publisher, Gdynia.
12. Pietrzykowski Z. (2008): Ship's fuzzy domain - A criterion for navigational safety in narrow fairways. Journal of Navigation, 61, 499-514.

13. Pietrzykowski Z., Uriasz J. (2003): Methods of artificial intelligence in navigational safety assessment of ship encounters. Proc. of Computer and Information Technology Applications in the Maritime Industries COMPIT 2003, Hamburg.

14. Pietrzykowski Z., Uriasz J. (2009): The ship domain A criterion of navigational safety assessment in an open sea area. The Journal of Navigation, 62, 93-108.

15. Porada J. (1972): Theoretical and practical reasons for determining the permissible speed of ships on fairway and navigational channels. In Polish: Teoretyczne i praktyczne przesłanki ustalenia dopuszczalnej prędkości statków na torach i w kanałach morskich, TGM 3 Poland.

16. Rutkowski G. (2016): Determining ship's safe speed and best possible speed for sea voyage legs. DOI: 10.12716/1001.10.03.07, ISSN 2083-6473 EISSN: 2083-6481, TransNav - The International Journal on Marine Navigation and Safety of Sea Transportation, 10 (3), 425-430.

17. Rutkowski G. (2018): ECDIS limitations, data reliability, alarm management and safety settings recommended for passage planning and route monitoring on VLCC tankers. TransNav - The International Journal on Marine Navigation and Safety of Sea Transportation, 12, 483-490.

18. Rutkowski G. (2019): Determining the optimal ship's safe speed, 1st Ed., LAP Lambert Academic Publishing, ISBN 97862000074 21, Printed by Schaltungsdientst Lange o.H.G., Berlin 2019 by European Union OmniScriptum Publishing Group, 2019-04-26.

19. Rutkowski G. (2019): Voyage planning, seafarers' competencies and watchkeeping procedures in the restricted sea areas, in the narrow channels and sharp bend fairways, 1st Ed., LAP Lambert Academic Publishing, ISBN 9786200094148, Printed by Schaltungsdientst Lange o.H.G., Berlin 2019 by European Union OmniScriptum Publishing Group, 2019-05-13.

20. Schofield R. B. (1974): Speed of ships in restricted navigation channels. Journal of the Waterways, Harbours and Coastal Engineering Division, May 1974.

21. Vermeer H. (1977): The behaviour of a ship in restricted waters. International Shipbuilding Progress, No 280.

22. Wang Y. Y. (2016): An empirically-calibrated ship domain as a safety criterion for navigation in confined waters. Journal of Navigation, 69, 257-276. 
23. Wielgosz M., Pietrzykowski Z. (2012): Ship domain in the restricted area - Analysis of the influence of ship speed on the shape and size of the domain. Scientific Journals of the Maritime University of Szczecin, 30(102), 138-142.

24. Zhu X., Xu H. and Lin J. (2001): Domain and its model based on neural networks. Journal of Navigation, 54, 97-103.

25. Zong Z. (2017): An introduction to ship hydrodynamics. Lecture notes based on Tupper E. C. (2004) Introduction to Naval Architecture, 4th Edition, Elsevier.

\section{CONTACT WITH THE AUTHOR}

\section{Grzegorz Rutkowski}

e-mail:kptgrzegorzrutkowski@gmail.com

Gdynia Maritime University, Morska 81-87, 81-225 Gdynia,

Poland

Master Mariners Association,

Al. Jana Pawła II 3, 81-963 Gdynia,

Poland 